\title{
SPATIAL DATA WEB SERVICES PRICING MODEL INFRASTRUCTURE
}

\author{
L.Ozmus $^{1}$,B.Erkek ${ }^{2}$, S.Colak $^{3}$, I.Cankurt ${ }^{4}$ and S.Bakıc1 ${ }^{5}$
}

\author{
${ }^{1}$ General Directorate of Land Registry and Cadastre, Ankara,Turkey,lozmus@ gmail.com \\ ${ }^{2}$ General Directorate of Land Registry and Cadastre, Ankara,Turkey, berkek@tkgm.gov.tr \\ ${ }^{3}$ General Directorate of Land Registry and Cadastre, Ankara,Turkey,sclok2000@gmail.com \\ ${ }^{4}$ General Directorate of Land Registry and Cadastre, Ankara,Turkey, icankurt@gmail.com \\ ${ }^{5}$ General Directorate of Land Registry and Cadastre, Ankara,Turkey, sbakici@tkgm.gov.tr
}

Commission II, WG II/2

KEY WORDS: Spatial Data, Orthophoto, Web Services, Data Pricing, Data Sharing, Licensing

\begin{abstract}
:
The General Directorate of Land Registry and Cadastre (TKGM) which is the leader in the field of cartography largely continues its missions which are; to keep and update land registry and cadastre system of the country under the responsibility of the treasure, to perform transactions related to real estate and to establish Turkish national spatial information system.. TKGM a public agency has completed many projects. Such as; Continuously Operating GPS Reference Stations (TUSAGA-Aktif), Geo-Metadata Portal (HBB), Orthophoto-Base Map Production and web services, Completion of Initial Cadastre, Cadastral Renovation Project (TKMP), Land Registry and Cadastre Information System (TAKBIS), Turkish National Spatial Data Infrastructure Project (TNSDI), Ottoman Land Registry Archive Information System (TARBIS). TKGM provides updated map and map information to not only public institutions but also to related society in the name of social responsibility principals.
\end{abstract}

Turkish National Spatial Data Infrastructure activities have been started by the motivation of Circular No. 2003/48 which was declared by Turkish Prime Ministry in 2003 within the context of e-Transformation of Turkey Short-term Action Plan. Action No.47 in the mentioned action plan implies that "A Feasibility Study shall be made in order to establish the Turkish National Spatial Data Infrastructure" whose responsibility has been given to General Directorate of Land Registry and Cadastre. Feasibility report of NSDI has been completed in 10th of December 2010. After decision of Steering Committee, feasibility report has been send to Development Bank (old name State Planning Organization) for further evaluation. There are two main arrangements with related this project (feasibility report).First; Now there is only one Ministry which is Ministry of Environment and Urbanism responsible for establishment, operating and all national level activities of NSDI. And Second arrangement is related to institutional Level. The most important law with related NSDI is the establishment of General Directorate of Geographic Information System under the Ministry of Environment and Urbanism. due to; to do or to have do works and activities with related to the establishment of National Geographic Information Systems (NGIS), usage of NGIS and improvements of NGIS

Outputs of these projects are served to not only public administration but also to Turkish society. Today for example, TAKBIS data (cadastre services) are shared more than 50 institutions by Web services, Tusaga-Aktif system has more than 3800 users who are having real-time GPS data correction, Orthophoto WMS services has been started for two years as a charge of free.

Today there is great discussion about data pricing among the institutions. Some of them think that the pricing is storage of the data. Some of them think that the pricing is value of data itself. There is no certain rule about pricing. On this paper firstly, pricing of data storage and later on spatial data pricing models in different countries are investigated to improve institutional understanding in Turkey.

\section{INTRODUCTION}

Turkish National Spatial Data Infrastructure activities have been started by the motivation of Circular No. 2003/48 which was declared by Turkish Prime Ministry in 2003 within the context of e-Transformation of Turkey Short-term Action Plan. Action No.47 in the mentioned action plan implies that "A Feasibility Study shall be made in order to establish the Turkish National Spatial Data Infrastructure" whose responsibility has been given to General Directorate of Land Registry and Cadastre. Feasibility report of NSDI has been completed in 10th of Dececmber 2010. After decision of Steering Committee, feasibility report has been send to Develpment Bank(old name State Planning Organization) for further evaluation.
Some purposed headlines are indicated below from feasibility report which is included needs and capacity analysis, socioeconomic analysis, risk analysis, implementation budget, NSDI institutional structure, technical infrastructure and related tender documents, legislative infrastructure, etc...

- There should be GIS units which collect data, manage data, serving data and having GIS experts in every GIS related institution.

- There should be a unique institution which is responsible for NSDI management based a law.

- There should be more investment for GIS education

- Duplication in hardware, software and data production investment should be prevented. 
- National standards should be revised according to ISO and OGC standards

- $\quad$ There should be a legislation for data access, data sharing and data pricing, etc

- $\quad$ There should be more awareness activities about NSDI

- $\quad$ Base data theme and data producer are identified

- Duplicated data production should be prevented

- Central or distributed system node are purposed

A first arrangement is related to Ministry Level with related feasibilyt report. Now there is only one Ministry which is Ministry of Environment and Urbanism responsible for establishment, operating and all national level activities of NSDI.

Second arrangement is related to institutional Level. The most important law with related NSDI is the establishment of General Directorate of Geographic Information System under the Ministry of Environment and Urbanism due to; To do or to have do works and activities with related to the establishment of National Geographic Information Systems (NGIS), usage of NGIS and improvements of NGIS.

- to do coordination and to do promotion for effective and efficient usage of contemporary geographic information technologies in the country.

- to provide determination of data sharing policy standards, data quality standards and data production standards in national level with its fundamental strategies and policies and to prepare required legislation

- to represent of our country in activities about Geographic Information Systems organized by national and international institution and foundation, to coordinate collaboration and compliance works

- All matters covered by the National Geographic Information System, to provide usage and evaluation by the Ministry units of the data which are produced by public and private agencies and organizations

- To establish and develop Ministerial spatial data infrastructure and to provide all kind of needed data due to effectiveness of Ministry

- To do all necessary arrangements for Urban Information System Standard to provide usage widely

- To establish and operate portal to serve spatial data produced by public and private institutions and organizations in the concept of National Geographic Information System

- To join international data sharing network

- To provide certification and accreditation works with related Geographic Information Systems

- To carry out application, arrangements, developments and monitoring activities with related to remote sensing and management, automation and documentation of navigation system supplement to GIS applications.

- $\quad$ To do IT works of Ministry

Today there is a great disccussion about data pricing among the institutions. Some of them think that the pricing is the storage of the data. Some of them think that the pricing is the value of data itself. There is no certain rule about pricing. On this paper after reviewing of the some literatures, firstly, pricing of data storage and than spatial data pricing models in diffrent countries are investigated and later on some recommendations are expressed.

\section{COMPARISON OF CLOUD DATA STORAGE COST}

In order to provide the most accurate comparison, typical data storage and usage scenario is considered in following examples. Approximately 2 Terabytes of storage with 500GB inbound data transfer and 100GB Outbound data transfer, which mimics a possible real world usage for an organization is being considered. In other words, for around $2 \mathrm{~TB}$ of data being stored, the company has some 500GB inbound data transfer every month (assuming about $25 \%$ of data changes every month), and around 100GB worth of data retrieval per month (average use). Following tables shows some comparisons.

\begin{tabular}{|l|c|c|c|c|c|c|c|}
\hline Monthly & $\begin{array}{c}\text { Amazon } \\
\text { Cloud Drive }\end{array}$ & $\begin{array}{c}\text { Apple } \\
\text { iCloud }\end{array}$ & Box & Dropbox & $\begin{array}{c}\text { Google } \\
\text { Drive }\end{array}$ & $\begin{array}{c}\text { Microsoft } \\
\text { SkyDrive }\end{array}$ & Mean \\
\hline $\mathbf{1 0 0}$ GB & $8,33 \$$ & $8,33 \$$ & $\begin{array}{c}1000 \mathrm{~GB} \\
15 \$\end{array}$ & $9,99 \$$ & $4,99 \$$ & $4,16 \$$ & $\mathbf{6 . 2 2} \$$ \\
\hline
\end{tabular}
karsilastirmasi/

\begin{tabular}{|l|c|c|c|c|}
\hline Vendor & 1 TB & 3 TB & 5 TB & 10 TB \\
\hline Symform - Bucks & $\$ 1,800$ & $\$ 5,400$ & $\$ 9,000$ & $\$ 18,000$ \\
\hline Carbonite Business & $\$ 1,044$ & $\$ 2,824$ & $\$ 4,604$ & $\$ 9,054$ \\
\hline MozyPro & $\$ 4,510$ & $\$ 13,530$ & $\$ 22,550$ & $\$ 45,100$ \\
\hline Acronis Online & $\$ 499$ & $\$ 1,497$ & $\$ 2,495$ & $\$ 4,990$ \\
\hline CrashPlan PRO & $\$ 2,899$ & $\$ 8,697$ & $\$ 14,495$ & $\$ 28,990$ \\
\hline $\begin{array}{l}100 \text { GB Month } \\
\text { MEAN }\end{array}$ & 17.50 & 52.00 & 86.50 & 172.74 \\
\hline
\end{tabular}

http://www.symform.com/our-solutions/pricing/storage-cost-comparison/

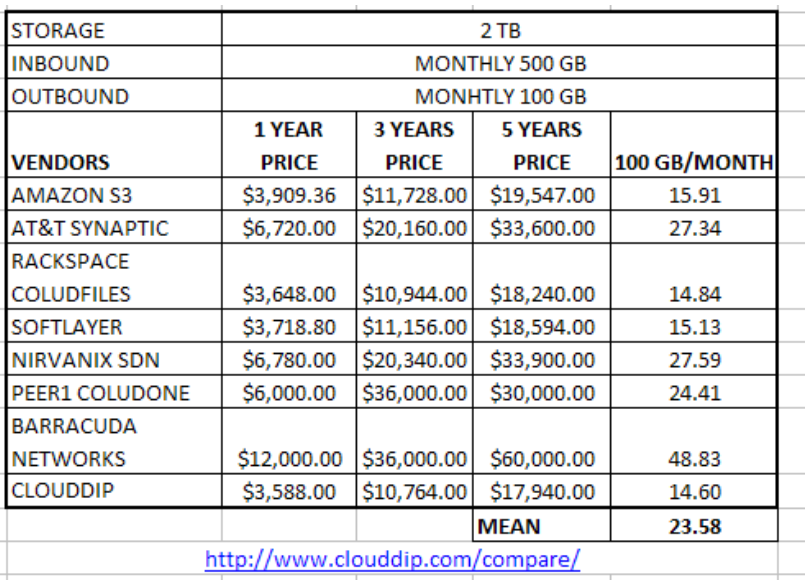

As a result of this comparison; price of $100 \mathrm{~GB}$ data storage on cloud data server is vary between $6 \$$ and $24 \$$ per month.

\section{COUNTRY EXAMPLES FOR DATA PRICING}

There three category for investigating country data pricing models. First, we consider here, Turkish NSDI feasibility report recommendations about data sharing and pricing policies. Secondly we consider, INSPIRE directive. And later we took as an example Lithuania, Germany and New Zealand data pricing models.

\subsection{Turkish NSDI feasibility Report}

The recommendations listed below are derived from the best practice seen in action in the six European nations visited in May 2010 by members of the Turkish NSDI Technical 
Committee, plus best practice as already noted and published by organisations such as EUROGI (via the eSDI-Net Plus project activities) and the GSDI Association, among others. However, the recommendations are also made from the viewpoint of the needs and prior situation in Turkey today.

\subsubsection{Policy Recommendations}

a) Define what data types (themes) are to be covered by the SDI following a consultation process with relevant stakeholders (both data producers and users). Examples of content for a typical SDI can be found in published documents for all the SDIs now under construction around the globe, in both developing and developed nations. Nearly all SDIs created to date divided the themes into 'core' or 'basic reference' data and 'thematic' data (see for example the list in Annex 5, from the INSPIRE Directive).

b) Establish who uses the datasets (data types) and who has primary responsibility for maintaining the datasets. This typically involves conducting a comprehensive information audit of all organisations' data holdings - and the purposes for which that data is held.

c) Set the data sharing principles and rules to encourage widest possible use of the data. Existing best practice, for example from Norway, where most SDI development has been on a voluntary basis, promotes the principle "share your data with the SDI (with other users) and you will get data back from the SDI (from other departments)". Data sharing also raises the debate - globally - over whether or not government departments should charge other users for access to their datasets. Even those nations that promote free access to, and use of, government data, also have business models that involve some element of charging for government data for certain uses, e.g. for commercial re-use. (See Business Models below).

d) Data owners should retain control over their data and access to it. Using distributed systems technology now readily available for geoweb services, this is readily achievable today. Users outside an organisation can access the data, as needed, typically online, without the need for exchanging whole datasets. This principle applies to metadata as well as data, although several SDIs do maintain some form of central (national) catalogue service (via an Internet portal) where all data owners can publish their metadata. Using modern and internationally standardized web map services (WMS), web feature services (WFS) and web processing services (WPS), there is little requirement for any user to need a full copy of a dataset from a data owner. Data ownership - and maintenance - should always be kept as close as possible to the organisation legally responsible for that dataset. In some cases, this will be a legal responsibility.

e) Set a viable data user and re-use/exploitation policy in line with the data sharing policy developed at (c) above. If data is to be shared widely and easily (via relevant interoperability specifications and technology), then to gain the most benefit (for both producers and users), there should be as few restrictions as possible (in line with the accepted Business Models) on re-use and exploitation of the datasets.

f) Ensure that the resulting SDI vision, strategy, implementation plan and related policies are in line with any higher level initiatives, such as those for developing a more inclusive Information Society, eGovernment, e-Democracy, etc. (In some cases, this may be a legal requirement).

\subsubsection{Business Model Recommendation}

Proposed Business Model in feasibility report, based on that followed by some of the most progressive and successful national SDIs reviewed, is one in which:

a) All web map services (WMS) contributing to the SDI should be at no charge.

b) Those agencies who contribute data to the SDI can receive data from other data suppliers on transparent, fair (previously agreed) and equivalent terms both in relation to any fees charged and uses permitted. This policy does not preclude charging for data, per se, only that charging regimes must be transparent and 'fair'. Remember that when one government department charges another government department for access to, or use of, its datasets - it is still the taxpayer (whose taxes support government) who is paying the bill! The value of such cross-subsidization has been called into question by numerous studies, compared to the cost of implementing such charging regimes.

c) Government data provided to non-governmental users should be made available under policies that include:

i. at no charge for non-commercial use by citizens and non-governmental organisations (NGOs),

ii. at no charge or small charge for noncommercial use by companies in conducting their businesses,

iii. at some charge, determined under transparent charging principles that apply to all government agencies, without exclusivity clauses (no monopolistic 
pricing), for commercial use of government supplied data.

d) In case (b-iii.) above, if a primary goal of the vision and strategy for implementing the SDI (and/or other government information programmes in which the initiative may be embedded, e.g. e-Government) is to generate greater economic growth for the nation, then the charges applied should be kept as low as possible - if one believes that freeing up government data will increase the size of the economy, i.e. generate new products and services, encourage formation of new businesses that will create employment and taxes, etc. Unfortunately every country is different, with widely varying underlying socioeconomic principles (cultural, entrepreneurial, taxation, etc.) and economic realities - especially in the current global recession. What may appear to be 'correct' and 'best practice' in one country is not necessarily 'best practice' in another - or even an achievable goal.

e) From a business perspective (according to the European PSI Alliance), what is as important as price for data (for commercial use) is having confidence in the quality of the data, especially if it is being used to develop a new product or service for which the company could be held accountable (if the data were of poor quality) and price stability, in order to develop and execute business plans that span a number of years.

f) Similarly, anti-competitive practices by government agencies should be avoided - and are illegal in most EU states. 'Anti-business' practices are less well regulated, i.e. a government agency might be forbidden by law from providing a data product or service that is not part of its legally mandated 'public task' (i.e. what legislation requires it to do), especially if private industry already offers an adequate product or service serving the same purpose, or could do so if it had access to the relevant government data.

\subsection{INSPIRE Directive}

Directive of the European Parliament and of the Council with related to "Establishing an Infrastructure for Spatial Information in the European Community (INSPIRE) says about data pricing; (19) Experience in the Member States has shown that it is important, for the successful implementation of an infrastructure for spatial information, that a minimum number of services be made available to the public free of charge. Member States should therefore make available, as a minimum and free of charge, the services for discovering and, subject to certain specific conditions, viewing spatial data sets. And under the "Network Services" of the Chapter 2 the needed services are defined as discovery services, view services, download services, transformation services and invoke services.Data pricing model is arranged in Article 14 and Article 17/3 and Article 14.INSPIRE data pricing model is shown following table.

\begin{tabular}{|c|c|c|c|c|}
\hline \multicolumn{5}{|c|}{$\begin{array}{l}\text { Directive of the European Parliament and of the Council with related to "Establishing an } \\
\text { Infrastructure for Spatial Information in the European Community (INSPIRE) }\end{array}$} \\
\hline \multicolumn{5}{|c|}{$\begin{array}{l}\text { (19) ........... a minimum number of services be made available to the public free of charge. Member States } \\
\text { should therefore make available, as a minimum and free of charge, the services for discovering and, subject to } \\
\text { certain specific conditions, viewing spatial data sets. }\end{array}$} \\
\hline \multicolumn{5}{|c|}{ 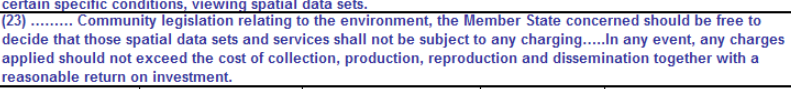 } \\
\hline & & & & \\
\hline SERVICES & Art 14-1 & Art. 14-2 & Art. 14-3 & Art. 14-4 \\
\hline $\begin{array}{l}\text { Art. 11-1(a) } \\
\text { DISCOVERY }\end{array}$ & $\begin{array}{l}\text { public free } \\
\text { of charge }\end{array}$ & & & \\
\hline $\begin{array}{l}\text { Art. 11-1(b) } \\
\text { VIEWER }\end{array}$ & $\begin{array}{l}\text { public free } \\
\text { of charge }\end{array}$ & $\begin{array}{c}\text { charges secure } \\
\text { the maintenance of spatial } \\
\text { data sets and } \\
\text { corresponding data } \\
\text { services }\end{array}$ & $\begin{array}{l}\text { preventing their } \\
\text { reuse } \\
\text { for commercial } \\
\text { purposes }\end{array}$ & $\begin{array}{l}\text { charges for the services....e } \\
\text { commerce services are } \\
\text { available. Such services }\end{array}$ \\
\hline \multicolumn{5}{|l|}{$\begin{array}{l}\text { Art. 11- 1(c) } \\
\text { DOWNLOAD }\end{array}$} \\
\hline \multicolumn{5}{|l|}{$\begin{array}{c}\text { Art. 11-1(d) } \\
\text { TRANSFORMATION }\end{array}$} \\
\hline \multicolumn{5}{|l|}{$\begin{array}{l}\text { Art. 11-1(e) } \\
\text { TALEP }\end{array}$} \\
\hline \multicolumn{5}{|c|}{ DATA SHARING } \\
\hline Art 17-3 & \begin{tabular}{|l|l|} 
Data and servis pre \\
Charges shall be \\
Community legisla \\
\end{tabular} & $\begin{array}{l}\text { nay have pricing and licens } \\
\text { the minimum level includi }\end{array}$ & Inot be subjec & $\begin{array}{l}\text { on investment } \\
\text { any charging }\end{array}$ \\
\hline
\end{tabular}

\subsection{Lithuanian Data Pricing Model}

Lithuanian data pricing model is based on 9 basic geoproduct types that differ depending on data type (raster/vector data sets, Web service), on the method of selection of territory by the user (select map sheets, draw territories), on rateable unit (map sheet, sq.km, click, period of time etc.) and on payment terms (after expiry of the license, before data production, periodically). In addition, price can be influenced by actual size of selected territory, number of selected map sheets, number of clicks, number of users, licensing period etc. With reference to business model there are implemented flexible licences and their confirmation possibilities in geoportal. According to purposes of data use data provider may choose suitable texts of license and possibilities of geoproduct's license confirmation (physical signature; electronic signature; agree with license in geoportal after proved identity; agree with license in geoportal).Lithuanian geodata products,services and pricing parameters are shown following tables.

\begin{tabular}{|c|c|c|c|c|c|c|c|c|c|}
\hline \multicolumn{10}{|c|}{ LITHUANIAN GEODATA PRODUCTS and SERVICES } \\
\hline TYPE & RD1 & RD2 & VD1 & VD2 & VD3 & ST1 & $\mathrm{ST} 2$ & $\mathrm{ST}_{\mathbf{3}}$ & ST4 \\
\hline DATA TYPE & \multicolumn{2}{|c|}{ Raster } & \multicolumn{3}{|c|}{ Vector } & \multicolumn{4}{|c|}{ Services } \\
\hline Price (Per) & Sheet & $\mathrm{Km} 2$ & Sheet & Km2 & Object & \multicolumn{2}{|c|}{ Period } & \multicolumn{2}{|c|}{ Click } \\
\hline $\begin{array}{l}\text { User } \\
\text { interaction }\end{array}$ & $\begin{array}{l}\text { Select } \\
\text { Sheet }\end{array}$ & $\begin{array}{l}\text { Draw } \\
\text { Area }\end{array}$ & $\begin{array}{l}\text { Select } \\
\text { Sheet }\end{array}$ & $\begin{array}{l}\text { Draw } \\
\text { Area, } \\
\text { Select } \\
\text { Layer }\end{array}$ & $\begin{array}{l}\text { Draw } \\
\text { Area, } \\
\text { Select } \\
\text { Object }\end{array}$ & \multicolumn{4}{|c|}{ Draw Area or Region } \\
\hline $\begin{array}{l}\text { System } \\
\text { interaction }\end{array}$ & $\begin{array}{l}\text { Select or } \\
\text { Cut Data }\end{array}$ & $\begin{array}{l}\text { Cut } \\
\text { Data }\end{array}$ & $\begin{array}{l}\text { Select } \\
\text { or Cut } \\
\text { Data }\end{array}$ & Cut Data & $\begin{array}{l}\text { Select } \\
\text { Object }\end{array}$ & \multicolumn{4}{|c|}{ Cut Window or select Data } \\
\hline Payment $^{*}$ & \multicolumn{5}{|c|}{$\mathrm{A}$ or $\mathrm{B}$} & A & B\&P & $\mathrm{A}$ & B\&P \\
\hline & \multirow{2}{*}{\multicolumn{5}{|c|}{ A-Ends at the end of the license period }} & & & & \\
\hline & & & & & & & & & \\
\hline & \multicolumn{5}{|c|}{$\begin{array}{l}\text { B-Before data production } \\
\text { P-Periyodicly }\end{array}$} & & & & \\
\hline
\end{tabular}

\begin{tabular}{|c|c|c|c|c|c|c|c|c|c|}
\hline \multicolumn{10}{|c|}{ LITHUANIAN GEODATA PRICING PARAMETERS } \\
\hline $\begin{array}{c}\text { PRODUCT } \\
\text { TYPE }\end{array}$ & RD1 & RD2 & VD1 & VD2 & VD3 & ST1 & ST2 & ST3 & ST4 \\
\hline $\begin{array}{l}\text { Number of } \\
\text { Region }\end{array}$ & + & & + & & & & & & \\
\hline Area & & + & & + & & & & & \\
\hline Layers & & & & + & & & & & \\
\hline $\begin{array}{l}\text { Number of } \\
\text { Objects }\end{array}$ & & & & & + & & & & \\
\hline Attribute Sets & & & & & + & & & & \\
\hline Usage period & & & & & & + & + & & \\
\hline Number of Click & & & & & & & & + & + \\
\hline Licence Type & + & + & + & + & + & + & + & + & + \\
\hline License Period & + & + & + & + & + & + & + & & \\
\hline Number of User & + & + & + & + & + & & & & \\
\hline $\begin{array}{l}\text { Ordering and } \\
\text { Delievering Cost }\end{array}$ & + & + & + & + & + & + & + & + & + \\
\hline Provision & + & + & + & + & + & + & + & + & + \\
\hline
\end{tabular}




\subsection{Germany Data Pricing Model}

Data prices have been geared to the needs of the geodata infrastructure existing within Europe (INSPIRE) and Germany (GDI-DE), thus opening up also the provision and accounting of the reference data through standardized Web services. The relevant recommendations on the determination of charges are based on the principles of calculating charges as valid in Europe and Germany, which means in particular on the principle of equivalence. Considering the economic and other values of the data, equivalent value measures for the use of the reference data were developed for the respective user.

Data prices have been divided into three fundamental components, which means part I containing the generally valid principles of charges and calcula-tion bases as well as part II with the special regulations on charges for the provision and use of reference data in the three product fields AFIS ${ }^{\circledR}$, ALKIS ${ }^{\circledR}$ and ATKIS $\AA$, as well as part III containing the glossary. Provision of the reference data includes the offline mode with the conventional information on and distribution of data as well as the online mode comprising the use of discovery, view and download services. The reference data can be referred to both internally for one's own use and also externally for the purpose of distribution to third parties. External use comprises dissemination of reference data with and without their modification in value added products and services of the respective user.

In the concept of the data pricing there is base price definetion and aditionaly some factors defined for data type, data size, liscensing and etc. which are shown table below.

\begin{tabular}{|c|c|c|c|}
\hline & \multirow{2}{*}{\multicolumn{2}{|c|}{ Format }} \\
\hline & & & \\
\hline AREA $\left[\mathrm{km}^{2}\right]$ & Factor & $\begin{array}{l}\text { Vector data with object } \\
\text { structure (NAS and }\end{array}$ & \\
\hline Up to 500 & 1 & comparable, as e.g. EDBS) & 1 \\
\hline 500 and 5.000 & 0.5 & Vector data with limited & \\
\hline 5.000 and 25.000 & 0.25 & object structure (SHAPE and & \\
\hline 25.000 and 50.000 & 0.125 & comparable) & 0.9 \\
\hline Over 50.000 & 0.0625 & Vector data without object & \\
\hline Number of Objects & \begin{tabular}{|l|} 
Factor \\
\end{tabular} & structure (DXF and & \\
\hline Upto 1.000 & 1 & comparable) & 0.5 \\
\hline 1.000 and 10.000 & 0.5 & Raster data (TIFF and & \\
\hline 10.000 and 100.000 & 0.25 & comparable) & 0.25 \\
\hline 100.000 and 1.000 .000 & 0.125 & Workstation Number & Factor \\
\hline Over 1.000 .000 & 0.0625 & 1 and 5 & 1 \\
\hline Million Pixel [MPx] & Factor & 6 and 20 & 1.5 \\
\hline Upto 1.000 & Patio & 21 and 100 & 2 \\
\hline & & Over 100 & 2.5 \\
\hline 1.000 and 10.000 & 0.5 & Use & Factor \\
\hline 10.000 and 100.000 & 0.25 & Download with storage & 1 \\
\hline 100.000 and 1.000 .000 & 0.125 & \begin{tabular}{|l} 
Download without storage \\
\end{tabular} & \\
\hline 1.000 .000 and 10.000 .000 & 0.0625 & (vector data) & 0.5 \\
\hline 10.000 .000 and 100.000 .000 & 0.03125 & Download without storage & \\
\hline Over 100.000 .000 & 0.015625 & (raster data) & 0.1 \\
\hline
\end{tabular}

\subsection{New Zealand Data Pricing Model}

According to "The Declaration on Open and Transparent Government"; the government asserts that the data and information it holds on behalf of the public must be open, trusted and authoritative, well managed, readily available, without charge where possible, and reusable, both legally and technically. Personal and classified data and information must be protected.

There is free and unimpeded view only access, using the self help information and asking questions to LINZ geospatial data (excluding certain personal information. Users requiring courier delivery of data in excess of $3 \mathrm{~GB}$ will be required to pay the dissemination costs as quoted at the time of download. We tested in different size of data to download to see calculated dissemination cost which are shown below table.

\begin{tabular}{|c|c|c|c|}
\hline MEDLA & GB & FIYAT S & l GB S \\
\hline DVD & 3.8 & 34.45 & 9 \\
\hline DVD & 4.1 & 35.28 & 9 \\
\hline DVD & 6.8 & 41.96 & 6 \\
\hline USB & 9.4 & 48.45 & 5 \\
\hline USB & 10 & 51.24 & 5 \\
\hline USB & 13 & 56.48 & 4 \\
\hline
\end{tabular}

\section{RESULTS AND RECOMMENDATIONS}

Consequently our investigation about web services pricing model we recommend following statements and pricing model;

- Data usage policies / rules put forward,

- Data privacy policies / rules put forward,

- Guarantee the continuity of the services offered by Web services, put forward as a percentage,

- The data will be presented with Web services, data types, and data objects and data layers to reveal the costs,

- Presentation costs, licensing, privacy and user policies to be dealt with,

- Data provision costs, licensing schemes, privacy and user policies explicitly publication

- Metadata and imaging servilerinin to be free,

-WMS services to be free of the concerned person,

- Coordinate transformation services to be free,

- Sharing data via the Web (sales) wpos-(web pricing \& ordering service) is used,

- Test for the service to be provided free of geographic data services,

Maps and map information from the sample web services model can be presented by Germany and the costs described above, the following cost calculation model used

Raster (mapsheet) data

SUN_M= BAZ_FIY x Alan_F x DF_F x IST_F x IND_F x SURE

Raster (image) data

SUN_M= BAZ_FIY x MPX_F x DF_F x IST_F x IND_F x SURE

Vector data

SUN_M= BAZ_FIY x Alan_F x DF_F x IST_F x IND_F x SURE

Vector Object data

SUN_M= BAZ_FIY x OBJ_F x DF_F x IST_F $x$ IND_F $x$ SURE

The above calculation formulas, the subscription system, user management (subscription), and timeliness costs are not included. As a last word we can say;

- As stated in the feasibility report TUCBS, WMS services at least be given free of charge to NGOs and non-profit public bodies,

- downloading data via Web services, delivered by hand to approximately $50 \%$ is more advantageous, 
International Archives of the Photogrammetry, Remote Sensing and Spatial Information Sciences, Volume XL-2/W2, ISPRS 8th 3DGeolnfo Conference \& WG II/2 Workshop, 27 - 29 November 2013, Istanbul, Turkey

\section{REFERENCES}

- Billing Models for Geo Web Services - A Contribution to Create a Spatial Data Infrastructure in Switzerland

- Commonwealth Policy on Spatial Data Access and Pricing

- $\quad$ GIS meets E-Commerce: First Steps towards a General Architecture for Geodata Markets

- Pricing and Ordering in Lithuanian Geoportal

- Policy on the Pricing for and Copyright of Spatial Information Products and Services

- $\quad$ Building Lithuanian NSDI

- Country Report - Germany

- Finnish National Spatial Data Strategy

- Aspects of a Licensing and Pricing Model for a Multi- Producer pan-European Data Product

- Declaration on Open and Transparent Government

- SeaDataNet Data Policy

- Data as a Service: Pricing Models for the Future of Data

- Getting Returns on Investment on Digital Geospatial data

- Economic Assessment of Spatial Data Pricing and Access

- Geospatial Data Policy Study

- Structure of Geographic Information Infrastructure

- $\quad$ Land Information New Zealand (Fees and Charges) Regulations 2003

- Public Sector Geo Web Services: Which Business Model Will Pay for a Free Lunch?

- General conditions for the provision and use of data, services and products of the Bundesamt für Kartographie und Geodäsie (Federal Agency for Cartography and Geodesy)

- http://www.e-siber.com/web/bulut-bilisim-vedepolama-servislerinin-detayli-analiz-vekarsilastirmasi/

- http://www.symform.com/oursolutions/pricing/storage-cost-comparison/

- http://www.clouddip.com/compare/ 